Ann. Biol. anim. Bioch. Biophys., 1978, 18 (2 B), 573-583.

\title{
Sertoli cells and development of seminiferous epithelium
}

\author{
by Marie-Thérèse HOCHEREAU-de REVIERS, M. COUROT \\ with the technical assistance of Christine PERREAU and Claudine PISSELET \\ Station de Physiologie de la Reproduction, I. N. R. A., \\ Nouzilly, 37380 Monnaie, France.
}

Summary. Sertoli cells partially control the development of the seminiferous epithelium and spermatogenetic processes in mammals :

- Impuberal phase. Hypophysectomy of impuberal lambs results in a decrease in the total
number of Sertoli cells/testis while that of stem cells/testis is maintained. Type Ao sperma-
togonia divide but few type Al spermatogonia are observed. There is no development of
seminiferous epithelium. LH only, or FSH + LH supplementation respectively maintains or
stimulates mitotic activity of Sertoli cells. FSH or LH acts on the differentiation of spermato-
gonia. Hemicastration of the impuberal rat and calf results in an increase in Sertoli cell
and stem cell numbers in the remaining testis. Sertoli cell stocks are depressed after post-
hemicastration treatment with either testosterone or testis protein extract. Stem cell stocks
are only affected by treatment with testis protein extract. Rat testicular compensatory
hypertrophy is also inhibited by rete testis fluid.

- Prepubertal phase. In the prepubertal rat or lamb where mitotic activity of supporting cells has almost stopped, hypophysectomy results in a decrease in Sertoli cell number/ testis. Stem spermatogonia number/testis and the efficiency of spermatogenesis are largely decreased. FSH supplementation maintains these parameters in the rat. In the remaining testis of the prepubertal hemicastrated rat or calf Sertoli cell stocks are not modified while stem cell stocks are increased.

- Adult phase. Positive correlations between the total numbers of Sertoli cells, the total length of seminiferous tubules/testis and the total area of seminiferous epithelium have been observed in adult males of different species (rat, ram, bull). The total number of Sertoli cells/testis and stem cell stocks/testis were also correlated. After hypophysectomy of adult animals (rat or ram) Sertoli cell stocks/testis do not vary while spermatogonia stock and the efficiency of the spermatogenetic process are greatly affected. In the adult rat, stem spermatogonia and yield of spermatogonial divisions are maintained by FSH treatment while meiosis and spermiogenesis are supported by $\mathrm{LH}$ supplementation. In the hypophysectomized ram, testosterone treatment does not support normal spermatogenesis.

\section{Introduction.}

Sertoli cells occupy less than a third of the volume of the seminiferous tubules of mammals with active spermatogenesis. They represent a population of permanent somatic cells which do not divide in the adult (Steinberger and Steinberger, 1971) ; 
their total number remains fairly constant even after hypophysectomy (Clermont and Morgentaler, 1955 ; Bustos-Obregon, 1970). Their proliferation occurs by mitosis in the impuberal testis before germ cell differentiation (Attal and Courot, 1963 ; Courot, 1971). On the other hand, few germ cells are present in the impuberal testis; they multiply and differentiate with initiation of spermatogenesis and are numerically the most important in the adult.

The first morphologically visible event at the time of testis differentiation is Sertoli cell precursor enclosure of the gonocytes in a cord-like structure (Jost ef al., 1973). Germ cells are maintained in this central position for a long time, until the beginning of the initiation of spermatogenesis which only occurs when gonocytes come into contact with the basement membrane and differentiate into spermatogonia entering the spermatogenetic cycle (Courot, Hochereau-de Reviers and Ortavant, 1970). Later on, with the differentiation of the Sertoli-Sertoli junctions, spermatogonia and leptotene primary spermatocytes are maintained in the basal compartment of the tubules, the more elaborated germ cells being in the adluminal compartment where they are still surrounded by cytoplasmic processes of Sertoli cells (Dym and Fawcett, 1970).

The morphological relationships between germ cells and Sertoli cells are indicative of interactions, and possibly of regulations, between these cells. We have been interested in these relations and this paper reports our quantitative observations on supporting and Sertoli cells and on gonocytes and stem spermatogonia in the rat, ram and bull in different physiological or experimental conditions.

\section{Material and methods.}

Animals and treatments. - Impuberal young rats were hemicastrated when 510 days old and killed at 18 or 60 days of age. Groups of 10-15 animals were treated daily for one or two weeks after hemicastration with testicular extract or testosterone (Hochereau-de Reviers and de Reviers, 1978) and ram rete testis fluid (Hochereau-de Reviers et al., 1977).

Young males with "Sertoli cell only » (SCO) testes were obtained by treating pregnant rats with busulfan $(20 \mathrm{mg} / \mathrm{kg})$ on day 20 of gestation. They were treated as previously described (Hochereau-de Reviers et al., unpublished results).

Prepubertal rats were hemicastrated when 23 days old and killed at 38 days of age. Prepubertal 28-day old or adult rats were hypophysectomized and treated for 14 days with FSH or LH (Ortavant, Courot and de Reviers, 1969).

Impuberal 50-day old lambs, prepubertal 120-day old lambs and adult rams were hypophysectomized and supplemented with gonadotrophins or testosterone (Courot, 1971 ; Monet-Kuntz et al., 1976).

Impuberal calves were hemiscastrated when 4 months old and killed at 18 months of age.

Evaluation of cell populations. - The total length of seminiferous tubules, the total number of Sertoli cells and stem spermatogonia were determined as described by Attal and Courot (1963). In the bull and ram testis AO and A1 spermatogonia were countedisseparately (Hochereau-de Reviers, 1976), but in the rat testis they were counted together. 


\section{Results.}

\section{1. - Impuberal testis.}

In the impuberal testis there is no spermatogenetic activity. The seminiferous tubules contain only gonocytes and/or reserve stem spermatogonia (A0) plus some renewing stem spermatogonia (A1) as germ cells, and supporting cells, precursors of Sertoli cells, as somatic cells. This type of testis is already under either central or local regulation.

Hypophysectomy of impuberal lamb. - The impuberal lamb testis is under pituitary control as hypophysectomy resulted in a decrease in the length and diameter of the seminiferous tubule. In the tubules, supporting cells were mainly affected and regressed quantitatively ( 40 p. 100) in a similar way as did testicular weight. However, the germ cells seemed to be relatively insensitive as the stock population of AO stem spermatogonia was not significantly modified but the cells did not differentiate into A1 spermatogonia and no spermatogenetic activity took place.

Hormonal supplementation with LH plus FSH stimulated development of the supporting cells in hypophysectomized lambs, whereas $\mathrm{LH}$ alone maintained it (table 1). FSH or LH given separately or a combination of these hormones allowed the differentiation of $\mathrm{AO}$ to $\mathrm{A} 1$ and initiation of spermatogenesis. Thus the transition from $A 0$ to $A 1$ spermatogonia was related to endocrine control but it is not known whether it was direct or operating via supporting cells.

\section{TABLE 1}

Hormonal control of testis in impuberal 50-day old lamb

\begin{tabular}{|c|c|c|c|c|}
\hline & $\begin{array}{c}\text { Testis } \\
\text { weight }(\mathrm{g})\end{array}$ & $\begin{array}{l}\text { Supporting c. } \\
/ \text { testis } \times 10^{6}\end{array}$ & $\begin{array}{l}A_{0} \text { Spgonia } \\
\text { testis } \times 10^{6}\end{array}$ & $\begin{array}{r}A_{1} \text { Spgonia } \\
/ \text { testis } \times 10^{6}\end{array}$ \\
\hline 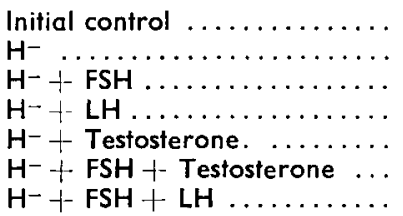 & $\begin{array}{l}3.1 \pm 0.5 \\
1.6 \pm 0.2 * \\
2.3 \pm 0.2^{*} \\
3.9 \pm 0.4 \\
2.0 \pm 0.2 * \\
2.5 \pm 0.6 \\
8.3 \pm 0.9 * *\end{array}$ & $\begin{array}{l}2360 \pm 160 \\
1400 \pm 140^{*} \\
1840 \pm 140^{*} \\
2540 \pm 300^{*} \\
1750 \pm 210^{*} \\
2000 \pm 30 \\
4580 \pm 600^{*}\end{array}$ & $\begin{array}{r}106 \pm 13 \\
91 \pm 10 \\
112 \pm 20 \\
113 \pm 24 \\
125 \pm 23 \\
126 \pm 9 \\
120 \pm 17\end{array}$ & $\begin{array}{l}3 \pm 2 \\
0.8 \\
5 \pm 4 \\
7 \pm 4 \\
3 \pm 2 \\
5 \pm 3 \\
25 \pm 10\end{array}$ \\
\hline
\end{tabular}

4 animals per group ; treated for 15 days ; $m \pm s m$; * : significantly different from initial control. FSH P15 CNRS : $9 \mathrm{mg} / \mathrm{d}$; LH P 8 CNRS : $4.7 \mathrm{mg} / \mathrm{d}$; Testosterone : $7.5 \mathrm{mg} / \mathrm{d}$.

Hemicastration. - Hemicastration of impuberal rats (5-10 days) or calves, (4 months of age) resulted in an increase in Sertoli cell number and stem spermatogonia in the remaining adult testis (tables 2 and 3 ). This could be due to modifications of the androgen levels or to some testicular cell factor. Proteinaceous rat testicular extract or testosterone over a period of 14 days after hemicastration partially inhi- 
TABLE 2

Effect of hemicastration on the remaining testis of rats

\begin{tabular}{lccccc}
\hline Animals & $\begin{array}{c}\text { Age (days) } \\
\text { Hemicastrated }\end{array}$ & Killed & $\begin{array}{c}\text { Testis } \\
\text { weight }(g)\end{array}$ & $\begin{array}{c}\text { Sertoli c. } \\
\text { /testis } \times 10^{6}\end{array}$ & $\begin{array}{c}\text { A Spgonia } \\
\text { /testis } \times 10^{6}\end{array}$ \\
\hline Normal ....... & - & 60 & $1.28 \pm 0.03$ & $54.2 \pm 2.9$ & $4.0 \pm 0.3$ \\
Hemicastrated.. & 5 & 60 & $1.75 \pm 0.06 *$ & $61.3 \pm 4.0$ & $4.5 \pm 0.5$ \\
Normal ...... & - & 38 & $0.35 \pm 0.04$ & $47.7 \pm 4.6$ & $3.0 \pm 0.4$ \\
Hemicastrated.. & 23 & 38 & $0.66 \pm 0.05 *$ & $44.8 \pm 2.1$ & $4.1 \pm 0.1 *$ \\
\hline
\end{tabular}

$m \pm s m \quad n=5 ;{ }^{*}:$ significantly different from normal.

TABLE 3

Effect of hemicastrotion on the remaining festis of 18-month old bulls

\begin{tabular}{|c|c|c|c|c|}
\hline & $\begin{array}{c}\text { Testis } \\
\text { weight }(g)\end{array}$ & $\begin{array}{l}\text { Sertoli c. } \\
\text { /testis } \times 10^{9}\end{array}$ & $\begin{array}{l}A_{0} \text { Spgonia } \\
\text { /testis } \times 10^{6}\end{array}$ & $\begin{array}{l}A_{1} \text { Spgonia } \\
/ \text { testis } \times 10^{6}\end{array}$ \\
\hline $\begin{array}{l}\text { Normal } \ldots \ldots \ldots \ldots \ldots \ldots \ldots \ldots \\
\text { Hemicastrated at } 4 \text { months of age.... }\end{array}$ & $\begin{array}{l}296 \pm 8 \\
399 \pm 33 *\end{array}$ & $\begin{array}{c}6.7 \pm 0.2 \\
11.9 \pm 1.6 *\end{array}$ & $\begin{array}{l}190 \pm 21 \\
390 \pm 90^{*}\end{array}$ & $\begin{array}{c}613 \pm 117 \\
1043 \pm 128 *\end{array}$ \\
\hline
\end{tabular}

$m \pm \operatorname{sm} \quad n=4 ; *$ : significantly different from normal.

TABLE 4

Inhibition of rat testicular compensatory hypertrophy by ram testicular extract, ram rete festis fluid, ram cauda epididymis plasma and ram seminal plasma

\begin{tabular}{|c|c|c|}
\hline Treatment & $\begin{array}{c}\left.\text { Testis weight ( }{ }^{1}\right) \\
\text { (mg) }\end{array}$ & Linear regression \\
\hline $\begin{array}{l}\text { Normal control } \ldots \ldots \ldots \ldots \ldots \ldots \ldots \ldots \\
\text { Hemicastrated } 10 \text { day-old control } \ldots \ldots \ldots \ldots \\
\text { HC }+ \text { RTE } \ldots \ldots \ldots \ldots \ldots \ldots \ldots \ldots \ldots \ldots \ldots \ldots \\
\text { HC }+ \text { RTF } \ldots \ldots \ldots \ldots \ldots \ldots \ldots \ldots \ldots \\
\text { HC }+ \text { CEP (diluted } 1 / 40) \ldots \ldots \ldots \ldots \ldots \ldots \\
\text { HC }+ \text { SP (diluted } 1 / 50) \ldots \ldots \ldots \ldots \ldots\end{array}$ & $\begin{array}{l}47.7 \\
70.1 \\
65.0^{*} \\
65.2^{*} \\
60.3^{*} \\
61.7^{*}\end{array}$ & $\begin{array}{l}1.012+0.021 \times \\
1.396+0.015 \times \\
1.065+0.023 \times \\
1.304+0.017 \times \\
1.076+0.026 \times \\
0.98+0.027 \times\end{array}$ \\
\hline
\end{tabular}

(1) Adjusted for body weight by covariance for a fixed weight of $30 \mathrm{g.}{ }^{*}$ : significantly different from HC control. Rats hemicastrated at 10 days, treated for 7 days and killed at 19 days of age. $n=15$.

bited (15 p. 100) the increase in the population of Sertoli cells in the remaining testis of rats observed 40 days after the end of treatment ( 60 days of age; table 5$)$. In the same experiment the stock population of A spermatogonia was lowered $(20$ p. 100) by administration of testicular extract and not by testosterone (table 5 ).

In 18-day old rats hemicastrated at 5 or 10 days of age, ram rete testis fluid and ram seminal plasma as well as ram testicular extract inhibited testicular compensatory hypertrophy (table 4), but this action was transitory and the total num- 
bers of stem cells and Sertoli cells in 60-day old rats were not significantly different in control and treated animals (table 5).

\section{TABLE 5}

Action of liver extract, festicular extract from adult rats, ram rete testis fluid and testosterone on hemicastrated 60-day old rats

\begin{tabular}{|c|c|c|c|}
\hline & $\begin{array}{c}\text { Testis weight } \\
\text { (g) }\end{array}$ & $\begin{array}{l}\text { Sertoli c./testis } \\
\times 10^{6}\end{array}$ & $\begin{array}{c}\text { A Spgonia/testis } \\
\times 10^{6}\end{array}$ \\
\hline 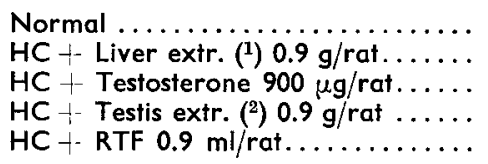 & $\begin{array}{l}1.28 \pm 0.03 a\left(^{3}\right) \\
1.75 \pm 0.06 b \\
1.33 \pm 0.07 a \\
1.50 \pm 0.04 \\
1.86 \pm 0.05 b\end{array}$ & $\begin{array}{l}54.2 \pm 2.9 a \\
61.3 \pm 4.0 \mathrm{~b} \\
55.3 \pm 2.3 \mathrm{a} \\
55.5 \pm 3.5 \mathrm{a} \\
65.3 \pm 2.9 \mathrm{~b}\end{array}$ & $\begin{array}{l}4.0 \pm 0.3 a \\
4.5 \pm 0.5 a \\
4.7 \pm 0.4 a \\
3.5 \pm 0.4 \\
4.8 \pm 0.2 a\end{array}$ \\
\hline
\end{tabular}

Animals hemicastrated at 5 days and treated for 14 days ; $m \pm s m, n=5$.

(1) $\mathrm{HC}+$ liver extract are considered as $\mathrm{HC}$ control (to be compared to $\mathrm{HC}+$ treatments) ; $\left({ }^{2}\right)$ Testis extract was not charcoal-extracted to prevent loss of low molecular weight proteins ; $\left({ }^{3}\right)$ Mean followed by the same letter are not significantly different.

In hemicastrated 18-day old SCO rats, tenfold-concentrated ram rete testis fluid modified the diameter of the seminiferous tubules but not the total number of Sertoli cells in testis as obtained with ram testis extract (table 6).

\section{TABLE 6}

Effect of hemicastration, RTF and testicular extract $(0.4 \mathrm{ml} / \mathrm{rat})$ on testis of 18-day old SCO rats

\begin{tabular}{|c|c|c|c|c|}
\hline Treatment & $\begin{array}{c}\text { Body weight } \\
\text { (g) }\end{array}$ & $\begin{array}{c}\text { Testis weight } \\
\text { (mg) }\end{array}$ & $\begin{array}{c}\text { Seminiferous } \\
\text { tubule diameter } \\
(\mu \mathrm{m})\end{array}$ & $\begin{array}{c}\text { Sertoli c./testis } \\
\times 10^{6}\end{array}$ \\
\hline $\begin{array}{l}\text { Normal } \ldots \ldots \ldots \ldots \ldots \ldots \\
\text { Hemicastrated } \ldots \ldots \ldots \ldots \\
\text { Hemicastrated }+ \text { RTF } \\
\text { Hemicastrated }+ \text { RTF } \times\end{array}$ & $\begin{array}{l}29.7 \pm 2.9 \text { a (1) } \\
32.7 \pm 1.1 \\
31.7 \pm 2.5 \text { a }\end{array}$ & $\begin{array}{l}24.5 \pm 1.1 \\
38.7 \pm 1.1 \mathrm{a} \\
36.9 \pm 1.1 \mathrm{a}\end{array}$ & $\begin{array}{l}70.2 \pm 0.9 a \\
78.4 \pm 0.8 b \\
76.3 \pm 1.0 b\end{array}$ & $\begin{array}{l}23.4 \pm 2.1 b \\
30.7 \pm 0.4 a \\
28.2 \pm 1.8 \mathrm{a}\end{array}$ \\
\hline Hemicastrated + testis & $29.0 \pm 0.4 a$ & $\begin{array}{l}31.5 \pm 0.5 b \\
29.9+0.8 b\end{array}$ & $69.1 \pm 2.0 \mathrm{a}$ & $29.4 \pm 2.3 a$ \\
\hline
\end{tabular}

$m \pm s m, n=5 ;\left(^{1}\right)$ Means followed by the same letter are not significantly different.

Thus the total number of Sertoli cells per testis was either directly or indirectly controlled by testosterone and by a proteinaceous subsiance secreted from the testis. On the other hand, Sertoli cells secreted a protein in the rete testis fluid and in the seminal plasma regulating the diameter of the seminiferous tubules and Sertoli cell activity (table 6). 
2. - Prepubertal animals.

The prepubertal testis is characterized by the onset of spermatogenetic activity, the arrest of mitotic activity of supporting cells and their maturation into Sertoli cells.

Hypophysectomy. - The prepubertal testis is under pituitary control. Hypophysectomy resulted in a regression of the seminiferous tubules while Sertoli cells decreased in number (minus 20 p. 100 and 40 p. 100 for lamb and rat, respectively), as did the stem spermatogonia (minus 66 p. 100 of $A 0+A 1$ spermatogonia in rat and of $A 1$ spermatogonia in lamb) (tables 7 and 8 ).

In the rat, LH did not maintain testis weight, while FSH did. Both hormones sustained Sertoli cells and A spermatogonia numbers in the testis (table 7).

TABLE 7

Pifuitary control of prepubertal 28-day old rat treated for 12 days

\begin{tabular}{|c|c|c|c|}
\hline & $\begin{array}{c}\text { Testis weight } \\
(\mathrm{mg})\end{array}$ & $\begin{array}{c}\text { Sertoli c./testis } \\
\times 10^{6}\end{array}$ & $\begin{array}{c}\text { A Spgonia/testis } \\
\times 10^{6}\end{array}$ \\
\hline $\begin{array}{l}\text { Normal .... } \\
\mathrm{H}^{-} \ldots \ldots . . . \\
\mathrm{H}^{-}+\text {LH } \ldots \\
\mathrm{H}^{-}+\text {FSH } .\end{array}$ & $\begin{array}{r}350 \pm 38 \\
43 \pm 3 \\
135 \pm 8 \\
472 \pm 26\end{array}$ & $\begin{array}{l}47.7 \pm 4.6 \text { a (1) } \\
35 \pm 1.7 \\
44.2 \pm 3.3 \mathrm{a} \\
54.0 \pm 6.4 \mathrm{a}\end{array}$ & $\begin{array}{l}3.0 \pm 0.4 a \\
1.0 \pm 0.1 \\
2.2 \pm 0.6 a \\
2.7 \pm 0.5 a\end{array}$ \\
\hline
\end{tabular}

$m \pm s m, n=3 ;\left({ }^{1}\right)$ Means followed by the same letter are not significantly different. FSH CNRS $M_{1}: 15 \mu \mathrm{g} / \mathrm{d} ;$ LH CNRS $M_{1}: 5 \mu \mathrm{g} / \mathrm{d}$.

In the 120-day old lamb, supplementation with testosierone was unable to maintain normal testis weight and stock populations of Sertoli cells and A1 spermatogonia in the testis. FSH and testosterone treatment supported the stock populations of A1 spermatogonia per testis but that of Sertoli cells was only partially maintained (table 8 ).

TABLE 8

Hormonal control of testis of prepubertal 120-day old lamb

\begin{tabular}{|c|c|c|c|c|}
\hline & $\begin{array}{l}\text { Testis } \\
\text { weight } \\
\text { (g) }\end{array}$ & $\begin{array}{l}\text { Sertoli c. } \\
/ \text { testis } \\
\times 10^{9}\end{array}$ & $\begin{array}{c}A_{0} \text { Spgonia } \\
/ \text { testis } \\
\times 10^{6}\end{array}$ & $\begin{array}{l}A_{1} \text { Spgonia } \\
/ \text { testis } \\
\times 10^{6}\end{array}$ \\
\hline 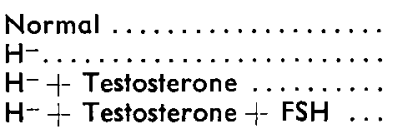 & $\begin{array}{l}45.0 \pm 5.4 a\left({ }^{1}\right) \\
17.7 \pm 1.9 \\
29.2 \pm 1.3 \\
51.9 \pm 10.0 a\end{array}$ & $\begin{array}{l}4.6 \pm 0.3 \\
3.6 \pm 0.3 a \\
3.7 \pm 0.5 a \\
3.9 \pm 0.2 a\end{array}$ & $\begin{array}{l}99 \pm 27 a \\
72 \pm 15 a \\
82 \pm 29 a \\
71 \pm 17 a\end{array}$ & $\begin{aligned} 200 & \pm 25 a \\
55 & \pm 5 \\
129 & \pm 19 \\
217 & \pm 20 a\end{aligned}$ \\
\hline
\end{tabular}

5 animals per group, treated for 15 days ; $m \pm s m, n=4$ or 5 .

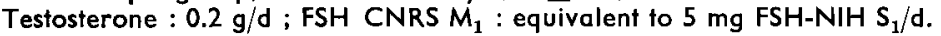

(1) Means followed by the same letter are not significantly different. 
Hemicastration. - Hemicastration of prepubertal 23-day old rat promoted hypertrophy of the remaining testis (table 2). There was an increase in stem spermatogonia but not in Sertoli cell numbers in the remaining testis. This resulted in a transitory hypertrophy which disappeared at adulthood.

Thus, the stock population of Sertoli cells was still gonadotropin-dependent during the maturation processes following the end of supporting cell mitoses. Total numbers of stem spermatogonia and the passage of $A 0$ to $A 1$ spermatogonia were under gonadotropin control.

\section{3. - Adult animals.}

In adult testes, Sertoli cell numbers did not vary significantly but stem spermatogonia varied either with a small increase long after puberty or with season in seasonally breeding animals. However Sertoli cell activity also showed seasonal variations.

Hypophysectomy. - Hypophysectomy in rat or ram provoked a sharp decrease in testis weight. The total number of Sertoli cells per testis was not affected while that of stem spermatogonia was drastically depressed : minus 30 p. 100, 12 or 24 days after hypophysectomy in rat, and 30 p. 100 and 70 p. 100 for AO and A1 spermatogonia 40 days after hypophysectomy in the ram (table 9).

In the rat FSH as well as LH maintained the total number of spermatogonia per testis. In the ram, testosterone supplementation was unable to maintain the normal number of stem spermatogonia per testis in spite of the usual intratesticular concentration of T and DHT (table 9 ).

\section{TABLE 9}

Effect of hypophysectomy and testosterone treatment on testis of adult rams

\begin{tabular}{|c|c|c|c|c|}
\hline Animals & $\begin{array}{l}\text { Testis } \\
\text { weight } \\
\text { (g) }\end{array}$ & $\begin{array}{l}\text { Sertoli } c . \\
\text { /testis } \\
\text { Y } 10^{8}\end{array}$ & $\begin{array}{c}A_{0} \text { Spgonia } \\
/ \text { testis } \\
\% 10^{6}\end{array}$ & $\begin{array}{l}A_{1} \text { Spgonia } \\
/ \text { testis } \\
\times 10^{6}\end{array}$ \\
\hline $\begin{array}{l}\text { Normal (Autumn) (14) } \ldots \ldots \ldots \ldots \ldots \ldots \ldots \\
H^{-} 40 \text { days }(4) \ldots \ldots \ldots \ldots \ldots \ldots \\
H^{-} 40 \text { days } f \text { testo }(5)(0.5 \mathrm{~g} / \text { day }) \ldots \ldots \ldots\end{array}$ & $\begin{array}{r}247 \pm 12 \\
70 \pm 7 \\
94 \pm 8\end{array}$ & $\begin{array}{l}63 \pm 4 \\
62 \pm 10 \\
43 \pm 4\end{array}$ & $\begin{array}{l}380 \pm 95 \\
258 \pm 48 \\
153 \pm 22\end{array}$ & $\begin{array}{l}450 \pm 43 \\
160 \pm 49 \\
120 \pm 29\end{array}$ \\
\hline
\end{tabular}

$\mathrm{m} \pm \mathrm{sm},(\mathrm{)}=\mathrm{n}$.

Hemicastration. - Hemicastration of adult rats or bulls did not change stem cell numbers, while in rams there was a large increase (around 50 p. 100) of A0 or A1 spermatogonia in both the non-breeding and breeding season.

In the adult rat, ram and bull significant correlations were observed between the stock populations of Sertoli cells and of $A 0+A 1$ spermatogonia (rat : $r=0.76$ ), and of A1 spermatogonia (bull : $r=0.72$; ram in the non-breeding season and in sexual season : 0.64 and 0.80 respectively).

So there appeared to be a clear dependence of the adult stem cell number upon the Sertoli cell population raised in the impuberal period, suggesting a local and a central feed-back control of Sertoli cells on the population of stem spermatogonia. 
However, stem cells and especially passage from reserve $A 0$ to renewing $A 1$ spermatogonia were also under gonadotropin control.

\section{Discussion.}

In the adult rat, ram and bull significant correlations between populations of Sertoli cells and of stem cells, especially the renewing A1 spermatogonia from which spermatogenetic cycle originated, show that testicular sperm production is regulated by events occuring a long time before, that is during impuberal phase when germinal cells divided slowly.

The onset of spermatogenesis takes place at the end of period of supporting cell mitoses (Clermont and Perey, 1957 ; Attal and Courot, 1963 ; Courot, 1971). At this time, stem spermatogonia move from the central part to the periphery of the tubule, in close contact with the basement membrane and perinuclear cytoplasm of Sertoli cells, outside the future Sertoli-Sertoli junction (Dym and Fawcett, 1970).

Multiplication and maturation of supporting cells are under hypophyseal control. Direct evidence was obtained after hypophysectomy and $\mathrm{FSH}+\mathrm{LH}$ supplementation in the lamb (Courot, 1971). In culture of rat Sertoli cells, FSH plays a role in enhancing residual mitoses and in promoting ABP secretion (Fritz ef al., 1976 ; Griswold ef al., 1977).

Cyproterone treatment of prepubertal rats resulted in an increase in the population of Sertoli cells possibly related to that of FSH and LH plasma levels (ViguierMartinez and Hochereau-de Reviers, 1977).

The regulatory action of proteinaceous testicular substance on number of Sertoli and stem cells of hemicastrated rats could be a direct one, like a chalone effect (Clermont and Mauger, 1974) or it could work through modification of gonadotropin levels. A decrease in plasma level of FSH after injections of testicular proteins was observed by Baker ef al. (1976) and Means et al. (1976).

Establishment of stock populations of stem spermatogonia is under hypophyseal control as after hypophysectomy there is hardly any appearance of A1 spermatogonia in the impuberal animal and a sharp regression occurs in the prepubertal or adult animals. Testosterone is unable to maintain this stock which is restored after FSH + LH treatment.

However antiandrogen (cyproterone or cyproterone acetate) in prepubertal rats prevents stem cell mitosis or differentiation, resulting in a depletion of the yield of spermatogonial divisions, either directly or by modification of Sertoli cell metabolism (Viguier-Martinez and Hochereau-de Reviers, 1977).

However, even though a central control of these populations is likely, a local interaction between them cannot be ruled out. The presence of differentiated germ cells in the seminiferous epithelium enhances Sertoli cell differentiation and secretion of ABP and Inhibin, while their absence in sterile or cryptorchid testis provokes a sharp increase of plasma FSH (De Krester, Burger and Hudson, 1973). On the other hand a precise arrangement of a definite optimal number of germ cells per Sertoli cell (Elftman, 1963 ; Stanley, 1966 ; Billard, 1969) suggests a direct control of Sertoli cells on yield of spermatogenesis. 
Finally, seasonal variations of secretion of rete testis fluid (Dacheux ef al., 1977) and of ABP (Jegou ef al., 1978), both indicative of Sertoli cell function, are similar to those of the basement membrane surface (Hochereau-de Reviers, Pelletier and Loir, 1976) and of testicular sperm production in ram (Dacheux et al., 1977).

Seminiferous tubules are in close contact with Leydig cells. A high and significant correlation $(0.80)$ is observed between the total number of A1 spermatogonia and the volume of intertubular tissue in the ram. This suggests that either Leydig cells and A1 spermatogonia are submitted to the same control or that, as testosterone is unable to support the populations of A1 spermatogonia, another substance secreted by Leydig cells acts on the stem spermatogonia.

In conclusion, gonadotropins are involved in the establishment of the population of Sertoli cells, as well as secretion of these cells, the initiation of spermatogenesis by passage from AO to A1 spermatogonia, and the yield of spermatogenesis. Steroids and proteinaceous testicular secretions are also implicated in these processes by central feed back at the hypothalamo-pituitary level and possibly by a local regulation within the seminiferous tubules.

27e Congrès infernational des Sciences physiologiques, Symposium "Germ and somatic cell inferaction " Paris, 21-23 juillet 1977.

Acknowledgements. - The authors are grateful to M. Blanc and J. L. Dacheux for furniture of RTF, CEP and SP and to Techni-Pharma for graciously supplying busulfan (Misulban). They wish to thank Dr Cahill and Mrs. Bossy for correction of the English text.

Résumé. Les cellules de Sertoli issues de la division des cellules de soutien sont formées avant l'établissement de la spermatogenèse ; elles contrôlent en partie le développement de l'épithélium séminifère.

- Phase impubère. L'hypophysectomie de l'agneau impubère entraîne une diminution du nombre total de cellules de Sertoli par testicule alors que celui des cellules germinales souches est maintenu. L'activité mitotique des cellules de Sertoli est maintenue ou restaurée par LH seule ou FSH + LH. En l'absence d'hypophyse il n'y a pas de différenciation des spermatogonies $\mathrm{AO}$ en $\mathrm{A1}$; celle-ci a lieu sous l'effet de FSH ou de LH. L'hémicastration de ratons impubères provoque une augmentation des cellules de Sertoli et des cellules souches dans le testicule restant. Ceł accroissement est inhibé par un traitement avec la testostérone ou des extraits protéïques de testicule. La population de spermatogonies souches est diminuée seulement par des extraits testiculaires.

- Phase prépubère. L'activiłé miłotique des cellules de Sertoli est à peu près nulle ; mais l'hypophysectomie entraîne touf de même une diminution de cette population cellulaire. Par ailleurs, le stock de cellules souches et l'efficacité de la spermatogenèse sont très fortement abaissés après hypophysectomie. La supplémentation par FSH maintient certains de ces paramètres chez le rat. L'hémicastration de rat ou de veau prépubère ne modifie pas le nombre de cellules de Sertoli dans le testicule restant mais augmente la population de spermatogonies souches.

- Phase adulte. Chez l'adulte (rat, bélier, taureau) il existe une corrélation positive entre le nombre total des cellules de Sertoli par testicule et celui des spermatogonies souches. L'hypophysectomie n'affecte pas le nombre total de cellules de Sertoli mais elle diminue la population de spermatogonies souches et l'efficacité de la spermatogenèse. Chez le rat 
adulte, FSH maintient la population de spermatogonies souches ainsi que le rendement des divisions spermatogoniales tandis que la méïose et la spermiogenèse sont mieux maintenues par LH. Chez le bélier hypophysectomisé, le traitement avec la testostérone ne maintient pas la population de spermatogonies souches ni le rendement des divisions spermatogoniales. L'hémicastration des béliers adultes modifie le stock de spermatogonies souches et l'efficacité de la spermatogenèse ; ceci n'est pas observé chez le rat ou le taureau.

\section{References}

ATTAL J., COUROT M., 1963. Développement testiculaire et établissement de la spermatogenèse chez le taureau. Ann. Biol. anim. Biochim. Biophys., 3, 219-242.

BAKER H. W. G., BREMNER W. J., BURGER H. G., de KRETSER D. M., DULMANIS A., EDDIE L. W., HUDSON B., KEOGH E. J., LEE V. W. K., RENNIE G. C., 1976. Testicular control of follicle stimulating hormone secretion. Recent Progr. Horm. Res., 32, 429-436.

BILLARD R., 1969. La spermatogenèse de Poecilia reficulata. I. Estimation du nombre de générations spermałogoniales et rendement de la spermatogenèse. Ann. Biol. anim. Biochim. Biophys., 9, 251-271.

BUSTOS-OBREGON E., 1970. On Sertoli cell number and distribution in rat testis. Arch. Biol., 81, 99-108.

CLERMONT Y., MAUGER A., 1974. Existence of a spermatogonial chalone in rat testis. Cell Tissue Kin., 7, 171-178.

CLERMONT Y., MORGENTALER H., 1955. Quantitative study of spermatogenesis in the hypophysectomized rat. Endocrinology, 57, 369-382.

CLERMONT Y., PEREY B., 1957. Quantitative study of the cell population of the seminiferous tubules in immature rats. Am. J. Anat., 100, 241-267.

COUROT M., 1971. Etablissement de la spermatogenèse chez l'agneau (ovis aries). Ełude expérimentale de son contrôle gonodotrope : importance des cellules de la lignée serfolienne. Thèse Paris, CNRS A. O., 6317.

COUROT M., HOCHEREAU-de REVIERS M. T., ORTAVANT R., 1970. Spermatogenesis, 339-432. In JOHNSON A. D., GOMES W. R., Van DEMARK N. L., The testis, Vol. 1, Acad. Press, New York and London.

COUROT M., ORTAVANT R., de REVIERS M. M., 1971. Variations du contrôle gonadotrope du testicule selon l'âge des animaux. Exp. anim., 4, 201-211.

DACHEUX J. L., PISSELET C., BLANC M. R., HOCHEREAU-de REVIERS M. T., COUROT M., 1977. Seasonal variation of rete testis fluid (RTF) production in the ram. Joint meeting SSF-SNESF (Nottingham, March 1977).

De KRESTER D. M., BURGER H. G., HUSDON B., 1973. The relationship between germinal cells and serum FSH levels in males with infertility. J. clin. Endocrinol. Metab., 38, 787-793.

DYM M., FAWCETT D. W., 1970. The blood testis barrier in the rat and the physiological comparfmentation of the seminiferous epithelium. Biol. Reprod., 3, 308-326.

ELFTMAN H., 1963. Sertoli cells and testis structure. Am. J. Anat., 113, 25-33.

FRITZ I. B., ROMMERTS F. G., LOUIS B. G., DORRINGTON J. H., 1976. Regulation by FSH and dibutyryl cyclic AMP of the formation of androgen-binding protein in Sertoli cell-enriched culture. J. Reprod. Fert., 46, 17-24.

GRISWOLD M. D., SOLARI A., TUNG P. S., FRITZ I. B., 1977. Stimulation by follicle-stimulating hormone of DNA synthesis and of mitosis in cultured Sertoli cells prepared from testes of immature rats. Mol. cellul. Endocr. 7, 151-165.

HOCHEREAU-de REVIERS M. T., 1976. Variation in the stock of testicular stem cells and in the yield of spermatogonial divisions in the ram and bull testes. Andrologia, 8, 137-146.

HOCHEREAU-de REVIERS M. T., BLANC M., COUROT M., DACHEUX J. L., PISSELET C., 1977. Inhibition of compensatory hypertrophy in the 10 days old hemicastrated rat by testis extract, rete testis fluid, cauda epididymis plasma and seminal plasma of ram. Joint meeting SSFSNESF (Nottingham, March 1977). 
HOCHEREAU-de REVIERS M. T., de REVIERS M., 1978. Analyse chez le raton hémicastré de la croissance compensatrice du testicule et de son inhibition par de l'extrait testiculaire ou de la testostérone. C. R. Acad. Sci. Paris (à paraître).

HOCHEREAU- de REVIERS M. T., PELLETIER J., LOIR M., 1976. Seasonal variations in the response of the testis and LH levels to hemicastration of adult rams. J. Reprod. Fert., 46, 203-209.

JEGOU B., DACHEUX J. L., TERQUI M., GARNIER D. H., COUROT M., 1978. Studies of the androgen binding protein in the rete testis fluid of the ram and the relation to sexual season. Mol. cellul. Endocr. (in press).

JOST A., VIGIER B., PREPIN J., PERCHELLET J. P., 1973. Studies on sex differentiation in mammals. Recent Progr. Horm. Res., 29, 1-41.

MEANS A., FAKUNDING J. L., HUCKINS C., TINDALL D. J., VITALE R., 1976. Follicle stimulating hormone, the Sertoli cell and spermatogenesis. Recent Progr. Horm. Res., 32, 477-527.

MONET-KUNTZ C., TERQUI M., LOCATELLI A., HOCHEREAU-de REVIERS M. T., COUROT M., 1976. Effet de la supplémentation en testostérone sur la spermatogenèse de béliers hypophysectomisés. C. R. Acad. Sci. Paris, sér. D, 283, 1763-1766.

ORTAVANT R., COUROT M., de REVIERS M. M., 1969. Activités spécifiques de différentes FSH et LH sur le testicule de mammifères. In La spécificité zoologique des hormones hypophysaires ef leurs activités. Coll. int. CNRS, $n^{0}$ 177, 369-379. CNRS, Paris.

STANLEY H. P., 1966. The structure and development of the seminiferous follicle in Scyliorhinus caniculus and Torpedo marmota (Elasmobranchii). Z. Zellforsch. Mikrosk. Anat., 75, 453-468.

STEINBERGER A., STEINBERGER E., 1971. Replication pattern of Sertoli cells in maturing rat testis in vivo and in organ culture. Biol. Reprod., 4, 84-87.

VIGUIER-MARTINEZ M. C., HOCHEREAU-de REVIERS M. T., 1977. Comparative action of cyproterone and cyproterone acetate on pituitary and plasma gonadotropins levels on male genital tract and spermatogenesis of perpubertal rats. Ann. Biol. anim. Bioch. Biophys., 17, 10691076. 